The University of San Francisco

USF Scholarship: a digital repository @ Gleeson Library |

Geschke Center

2014

\title{
Bankruptcy: The Divergent Cases of the City and the County of San Bernardino
}

Richard Callahan

University of San Francisco, rfcallahan@usfca.edu

Mark Pisano

Follow this and additional works at: http://repository.usfca.edu/pna

Part of the Business Commons, and the Economics Commons

\section{Recommended Citation}

Callahan, Richard F; Pisano, Mark. Bankruptcy: The Divergent Cases of the City and the County of San Bernardino. Public Finance and Management. 14.1 (2014): 84-105.

This Article is brought to you for free and open access by the School of Management at USF Scholarship: a digital repository @ Gleeson Library | Geschke Center. It has been accepted for inclusion in Public and Nonprofit Administration by an authorized administrator of USF Scholarship: a digital repository@ Gleeson Library | Geschke Center. For more information, please contact repository@usfca.edu. 


\title{
BANKRUPTCY: THE DIVERGENT CASES OF THE CITY AND THE COUNTY OF SAN BERNARDINO
}

\author{
Richard F. Callahan, University of San Francisco \\ and Mark Pisano, University of Southern California
}

\begin{abstract}
The cases are the two separate jurisdictions of the City of San Bernardino and the County of San Bernardino, California, U.S.A. The matched pair offers a unique opportunity for a research design that compares a bankrupt city government with a jurisdiction sharing the essential demographic, economic, and geographical features, though as a county a different level of government. The two cases offer insights into bankruptcy as not simply a function of economic forces or recent poor policy choices but as a result of a pattern of decision-making, a structure of government, and the constraints placed on leadership by structure and electoral politics. The analysis of this comparison allows us to unbundle leadership and show that differences in strategy, transparency, civic culture, trust and accountability explain the divergent outcomes.
\end{abstract}

\section{INTRODUCTION}

Not all state actors are created equal. A set of challenges exists in explaining the actions of public sector leaders who while being confronted with similar circumstances choose different paths and different strategies. A problem that needs to be addressed in public finance research is how to explain the divergent outcomes of similarly situated jurisdiction. The two contemporary case studies in this paper provide a unique opportunity to compare two similar situated circumstances, with two different set of state actors.

The cases are the two separate jurisdictions of the City of San Bernardino and the County of San Bernardino. These jurisdictions were at the epicenter of the collapse of the housing market in 2008. The San Bernardino region east of the Los Angeles region experienced one of the sharpest downturns in housing and employment in the United States. The City Council of San Bernardino approved filing for bankruptcy in July 2012. The County of San Bernardino Board of Supervisors approved a balanced budget in June 2012. The City is nested within the County. Both share not only geography, but also the devastating impact of the economic downturn in housing, employment, and tax revenues. Each of these jurisdictions suffered the housing market collapse in the immediate time frame, and both had experienced the exodus of industrial employment over the past two decades. These cases address the need for research that deepen the understanding of the social interactions in public finance (Slusher, 2011, 177). In addition, the cases advance the research on the use of 
municipal debt around risk-assessment, regulation, and the practical challenges facing financial managers (Martell and Kravchuk, 2012).

This paper proceeds as follows. In section one, we consider the basic logic of the problem, including research on budgets and finance in local government, as well as the findings from our research on fiscal sustainability in comparable cases in the region. In section two, we consider the cases of the City of San Bernardino and that of the County of San Bernardino. In section three, we resolve the problem with an explanation of the features that explain the divergent outcomes of the comparison cases and the implications.

\section{PART I: THE STATE OF PREVIOUS RESEARCH}

The existing research on bankruptcy is limited by the lack of opportunity for designing studies across comparable features. There are episodic cases, spread across a wide range of geography, spread out over years. Even with the significant reduction of tax revenue in the past five years for local governments in California, currently only five cities are considering, or have already filed for bankruptcy. The descriptive cases emphasized poor oversight of investments, as in the case of Orange County, or collective bargaining contracts that are unaffordable for salaries, health, and retirement benefits, as in the case of the City of Vallejo, or poor fiscal policy choices to foster economic growth, for example in the City of Stockton.

However, in each of the five current cases of bankruptcy in California, the differences between the cities are significantly greater than the similarity. To know one bankruptcy is to know none of the other bankruptcies. In practical terms, a comparison of Orange County and the City of Stockton would start with a list of different demographics, economies, population sizes, workforces, economic drivers, political cultures and a range of other factors that diverge institutionally, organizationally, and in the community. Additionally, the time frame separated by decades suggests another complication in comparisons. Similarly, a comparison of the cities of Stockton and Vallejo might best be described as alike in unimportant ways. As a well-developed urban, port city, in California's central valley, Stockton is far removed from the demographics and economics driving Vallejo as a suburb in the San Francisco Bay area community.

Extending this logic across the nation, the institutional design of counties in California is very different than comparable jurisdictions throughout the nation. The difficulty of finding comparable jurisdictions experiencing bankruptcy in one state of the United States, suggest an even greater difficulty in finding shared features on crossing state lines. Geography does matter for economic drivers, as well as for governance design features. In addition, the complexity of pressures include cyclical, structural, and intergovernmental 
(Chapman, 2008), as well as the "magical thinking" of residents wanting decreased taxation coupled with increased services (Korey, 2011). These factors suggest additional variance across geography in organizational and institutional design.

One of the great strengths of public finance research is the capacity to aggregate data across a range of jurisdictions, developing trend lines across jurisdictions, across time (see for example U.S. Government Accountability Office, 2013). However, in the absence of shared demographics, economic pressures, and institutional design, a large data set design becomes a weakness in exploring the shared features of bankruptcy. For example, the descriptions of local governments in the aggregate on the use of flexible budgeting does provide important insights generalized from surveying a local government jurisdictions (Beckett and Doamekpor, 2011), but does not provide internal insights as to the decision-making processes that lead to sustainable budgets, or conversely the decisions that can drive a local government to bankruptcy.

Describing the state of public finance across hundreds of jurisdictions does not get at the question of how each jurisdiction, with separately elected and appointed officials, arrived at a poor fiscal position. Research on the municipal debt market emphasizes the importance of financial managers balancing the trade-off between maintaining a good credit rating while borrowing for needed public projects but calls for more research on institutional design in protecting the public interest (Martel and Kravchuk, 2012, 674-675). Similarly, research that surveys performance management usage (e.g. Moynihan, 2008), can describe the motivation for using data or the conditions that make performance management data more readily used, but does not typically connect performance management research with fiscal performance in a bankruptcy filing by a city.

An additional limit to the current public finance research is developed by Wagner (2007) in a critique of research that emphasizes the state as an actor responding to events, as opposed to a model of public finance as driven by a complex set of social interactions. Along the lines suggested by Wagner, a recent public finance symposium on flexible budgeting emphasized the need to develop better explanations of resiliency in budgeting and the role of democratic practices in public finance (Sacco, Stalebrink, and Posner, 2011, 90).

The use of two case studies does not provide the basis for building or testing public finance theory. The research in public finance does provide theories or frameworks for budget decision-making (for example, the impact of politics in Wildavsky, 1961). The design of this paper is not to test existing theory or develop a new theory. Rather, the research design intends to take advantage of a natural experiment to contrast outcomes that occur in the same time frame and geography between San Bernardino County and City and presents an em- 
pirical puzzle that the existing literature does not fully explain. The implications of this research can be extended into the future to test a theory or framework of bankruptcy or fiscal stress across a wider range of jurisdiction, as is appropriate for theory development and testing.

\subsection{SOLUTION TO THE PUZZLE}

The matched pair research design of comparing a bankrupt city government with a jurisdiction sharing all the essential demographic, economic, and geographical features, though as a county a different level of government provides a unique opportunity. The essence of our contribution in this article is two fold: one, a research design that allows for a uniquely situated research comparison; two, an explanation of bankruptcy that balances the tension between the role of individuals, in effect leadership explanations, with the impact of organizational and institutional structure.

Our solution emerges from research into the two cases, but also out of our research on fiscal sustainability in city and county government for the past three years across a wide range of cases in other parts of Southern California (Callahan, 2012; Pisano and Callahan, 2012). The findings from these other cases provide a road map for a deeper understanding of the comparison of San Bernardino City and County. The two cases offer insights into bankruptcy as not simply a function of economic forces or recent poor policy choices but as a result of a pattern of decision-making, a structure of government, and the constraints placed on leadership by structure and electoral politics.

\section{PART II: THE CASES}

The basic logic of our approach is a comparison of the two case studies with considerable shared features, including geography, demographics, economy, same time frame, and similar residential housing. This provides an opportunity to move beyond the episodic study of bankrupt cities or counties. In particular, case study research is particularly well suited to get at the how question (Yin, 1994), with particular importance in understanding questions of governance (Hendrick, Hill, and Lynn, 2004). Moreover, case study research has proven particularly successful at explaining questions of arriving at sustainable self-governing solutions in environmental, common pool resource challenges (Ostrom, 2010). There is considerable precedence for research on municipal, special district, and county bankruptcy, with case studies in New York City, Orange County, California, and other jurisdictions.

The case study approach provides analytical leverage to deepen the understanding of municipal bankruptcy through researching the complex interactions of leadership, structure, and politics. In this section we develop each case 
study around similar features: the context: external economic forces, internal decision-making, structures, demographics, and revenues and expenditures.

\subsection{THE BANKRUPTCY OF THE CITY OF SAN BERNARDINO}

With a population of 209,938 , The City of San Bernardino, California is the $17^{\text {th }}$ largest city in the state and the $99^{\text {th }}$ largest city in the United States, according to the 2010 Census. In fiscal year 2012, the city reported revenue of \$ 115 million with expenses totaling \$ 128 million. The city is one of the poorest large cities in the nation. It is the county seat of San Bernardino, the largest county by land size in the nation. Finally, it is the largest city in the United States to declare bankruptcy under Chapter 9. The transition to bankruptcy has been dramatic, with the July, 2012 City Council approval filing a marked contrast to the 1978 recognition as an All-America City award by the National Civic League, the highest award given for Civic Performance.

\subsection{EXTERNAL CONTEXT}

Five external forces eroded fiscal sustainability. One, the loss of large employers that created a flight of middle class jobs. Two, transition to rental occupied housing. Three, construction of an interstate highway that isolated pockets of the community and changed the growth patterns. Four, the loss of redevelopment authority, coupled with a failure to expand the property tax base through annexation. Five, a national economic downturn coupled with decreased federal financial capacity to support cities.

The housing crash of 2008 exposed the City of San Bernardino to the perfect storm of devastating job losses, retail flight from the commercial center, an absentee landlord housing stock, demographics of a lower income population, and a state governor and legislature prioritizing state budget deficit reduction over local jurisdictions' budget needs. For three decades it was one located in one of the fastest growing counties in population and housing in the nation. Though the city offered affordable housing for the construction workers, starting in the late 1970's, the city suffered from the region's dramatic job losses. Approximately 10,000 jobs were lost with the closure of Kaiser, 12,500 jobs were lost with the closure of Norton Air Force Base and over 3,000 jobs lost with the movement of the railroad maintenance facility to Topeka. The housing price collapse starting in 2008 of the Great Recession led to the loss of a large number of residential construction jobs.

According to one estimate, of the 63,000 housing units, 43,000 single family and 20,000 apartments in the city, only 18,000 of the housing units have their tax bill sent to the property in which the resident lives, the remainder are sent to absentee landlords. Over $70 \%$ of the residents in the city 
are renters. The city had an unemployment rate of $18 \%$, with over $48 \%$ of the population on public assistance, and a median income of $\$ 38,640$.

The completion of the federal interstate highway program and regional development patterns adversely affected the city in this same period. In the late 1960's the construction the federal interstate highways facilitated development of the commercial centers to the west in the cities of Ontario and Rancho Cucamonga 15 miles west of San Bernardino. As these areas became the commercial center of the county, pulling the property and retail sales taxes from the City of San Bernardino, a once robust commercial and entertainment center rapidly declined. The city which once had 12 auto malls today has only five. Amplifying the impact of the freeways has been the formation of a separate city on the eastern boundaries with higher income unincorporated areas formed into the new City of Highland rather than annexing into the City of San Bernardino.

A more recent setback was the elimination by the governor and legislature of the redevelopment agencies in the state in 2011. Through previous California state law, cities and counties could form legally separate redevelopment agencies. The new entities were designed to address economic blight by stimulating local construction with the goal of expanding the property tax base. The increase in property tax collection in the defined geographical area would be dedicated to the redevelopment agency for a period of years to the redevelopment agency to fund operations and debt service. This loss of redevelopment agency authority shifted city redevelopment dedicated property taxes to the purpose of state deficit reduction. The loss of redevelopment tax increment funding dedicated to redevelopment projects in the city took away a major public policy tool for addressing the extensive and overwhelming urban blight, leaving the mayor and council without mechanisms to stimulate economic redevelopment in the downtown.

\subsection{INSTITUTIONAL CONTEXT}

The study of the internal conditions, the governmental structure and leadership further explains how this economic storm reverberated through the City of San Bernardino, leading to fiscal insolvency. Several features distinguish the institutional design of the City of San Bernardino that affected fiscal sustainability. In this case, three specific aspects of the institutional design significantly reduced the capacity of the city leadership to address the perfect storm of external events. These three features are nested together, with each aspect affecting the other. First, the charter law process; second, the use of the Charter to embed salary expenditures into a fix formula; and third, the centrality of the Office of the City Attorney to all policy making. 
First, a distinguishing feature of the City of San Bernardino was that it was established as a charter law city in 1906 using the authorities of state law that enabled the population of the city to vote through referendum to establish the processes and structure of the city government. The charter is central to understanding the fiscal transformation of the city from a fiscally challenged city to a dysfunctional and fiscally unsustainable and bankrupt city.

Second, a distinctive feature of electoral politics in the city has been the use of the charter to set operational and budgetary policies. For example, the charter establishes salaries for police and fire by specifying increases as the average of the annual increase in public safety units in ten specific cities in the state, all having stronger socio-economic contexts than the City of San Bernardino. The net effect has been regular increases that far exceeded the fiscal capacity of the city.

Third, the role of the City Attorney has been central to the operations and policy making in the city through a provision in the charter that established that only the city attorney has the authority to legally interpret the charter. The net effect of the charter provisions have given the city attorney policy authority over operational and financial issues within the city, creating conflicts between the office of the mayor and city attorney. Conflicts between offices within political jurisdictions are not unusual, but the conflicts and the climate for resolving these conflicts are so dysfunctional that a past mayor requested a restraining order on the city attorney. Additionally, the City Attorney's Office may have had the professional experience in other jurisdictions or in a career focused on public finance typically found in an office of a city manager or in a county chief executive office.

Fourth, the charter limited the powers of the executive functions. Neither, the Office of the Mayor nor the top appointed administrator had the power of the chief executive to pull together varied policy makers or to structure the decision making process to resolve the range of stakeholder differences that led to the bankruptcy filing.

\subsection{DECISION-MAKING}

Three features explain the expenditure choices that contributed to the fiscal collapse of the city: first, policy choices on salaries and pensions for public safety employees; second, a formal weak administrative structure; and third, the political drivers for increased expenditures.

First, in addition to the charter policies that regularly increased annual salaries at a rate more appropriate for other jurisdictions, the city council decision-making processes typically did not account for the long-term fiscal 
impact of decision. The most striking decision of the city council with intermediate and long-term fiscal consequences was the approval in 2004 for public safety personnel of a pension program of $3 \%$ at 50 years of age, i.e., pensions would be calculated at $3 \%$, rather than a lower percentage, for each year of service and retirement could start at 55 years of age. Additionally health coverage would be provided between 50 and 65 when Medicare eligibility starts. These policies create a situation in which eventually the city will be paying retirees more than active members of the public safety personnel. In the bankruptcy filing, longtime columnist on state and local government, Dan Walters noted that the state pension system, CalPERS, was listed as the "...largest single creditor at more than $\$ 140$ million and [the City of San Bernardino had] stopped making pension fund payments", with the CalPERS legal filing asserting that the "... the city was trying to improperly renege on its pension debts" (Walters, 2012).

Second, the long-standing structure had been with a city administrator form of government. To introduce increased discipline in financial management, the city moved from a city administrator to city manager structure in 2006. The cost structure of the city coupled with the changing external conditions over time put revenues on a steep downward spiral. Experienced city managers were brought in to improve the financial controls and reports to the council. The mayor organized policy retreats with experienced facilitators to create an understanding within the council that could address budget imbalances. These efforts did provide some momentum to change city policies but soon gave way to the politics of the city. Additionally, the city's former auditing firm has been changed, highlighting some of the limitations of past audits.

Third, the political dynamics drove increased expenditures. The politics of the city underlying council actions and charter amendments reduced fiscal capacity, eventually leading to the bankruptcy filing of the city. The political realities in elections were shaped by the changing external conditions. The changes in the economic and financial conditions of the city fundamentally reduced the civic capacity. The civic and political infrastructure had been the driving forces behind the successful bid to be designated an allAmerican City in 1978 eroded by the turn of the century.

The public safety unions for police and fire were well organized and funded. One interviewee claimed that less than $10 \%$ of the members of a 135 member uniform fire department live in the city. The labor unions representative for police and fire were politically impactful, with support for city council candidates translating to favorable outcomes on the council and in the community. For example, in the facilitated discussions at a retreat on the financial condition of the city, one of the council members suggested changes in pension policy. That council member's re-election was defeated 
the next year. In an election in his ward, the opponent's spending was in large part provided by the largest collective bargaining units of the city.

Public elections on the charter and council elections followed the same pattern. There is not a well-developed civic engagement strategy or process that offers moderating and balancing effects of other interests. Likewise an effort to reform the city charter led by Jim Morris, an attorney who served as an unpaid assistant to the Mayor - his father-was defeated by the electorate. The warnings raised in the reform campaign failed to move the city from the road to fiscal insolvency. Along similar lines, the reports of fiscal unsustainability by the Mayor and a consulting firm, Management Partners, in 2006 (Morris, 2010) did not move the city council to action in the face of electoral dynamics.

\subsection{THE DYNAMICS OF DECLARING BANKRUPTCY}

In 2010, the Mayor and City Manager reported that the city was on a path to fiscal insolvency with immediate steps needed or the city could face the possibility of bankruptcy. The Mayor wrote a newspaper editorial section column (Morris, 2010) warning of the same possibility. The fiscal condition steadily declined until the budget deliberations in spring and summer 2012. By this time the city had amassed an unfunded liability of $\$ 150$ million dollars to the state retirement system and other creditors.

Also, affecting the 2012 budget deliberations was the immediate impact of Governor and legislature eliminating local redevelopment agencies was to reduce the operating revenues that supported positions in the city by $\$ 6$ million. The timing of the state's fiscal problems and the city's continual slide created the proverbial perfect storm that fiscally devastated the city.

The deliberations of the 2012 budget became desperate. Not only was the budget projected to run a large deficit, but also the city's cash reserves were depleted with the city unable to borrow from other cash accounts. A controversy developed over the legality of shifting funds from one dedicated account to another. But this discussion could not ignore the structural deficits that the Wall Street Journal (2012) editorial writers described as projected “...\$45 million annual deficits for the next five years".

With cash flow an immediate and pressing problem, the Mayor and the City Manager in two months reduced the operating deficit by $\$ 18$ million by taking all service to minimum levels, including reductions in police and fire services. In one interview, an assessment was shared that further operation costs reduction, outside of police and fire, could only be achieved through the actual closing of entire functions and departments. The fiscal outlook for 
the 2012 budget year was a projected $\$ 240$ million of debt, including $\$ 47$ million in pension obligations, with $\$ 115$ million of projected revenue.

At the Council meeting of July 10, 20121 the City Attorney recommended to the council that to protect the city they should file for bankruptcy. In a situation described by the reporter for the Los Angeles Times (Willow, 2012, p. A1), “...so dire that it could not cover payroll through the summer." The local newspaper, displayed on the front page the day after the City Council approval of the bankruptcy filing that the City's budget expenditures had increased from \$144 million in fiscal year 2008-09 to \$166 million in FY 2012-13. The dysfunctional structure played itself out in the council meeting with the City Attorney quoted as saying, "the Mayor and Council were not given accurate documents" (Willow, p. A10). The Mayor disputed the City Attorney's account. The Council voted to initiate bankruptcy.

\subsection{AVOIDING BANKRUPTCY: THE COUNTY EXTERNAL CON- TEXT}

The County of San Bernardino is the largest geographic county in the United States. The County's considerable undeveloped landscape, with driving proximity for commuters working in Los Angeles City and County had invited a housing construction boom. With the downturn of the economy in the United States, the housing construction collapsed in 2008, with many new homeowners no longer able to afford mortgages because of job loss or other factors affecting their personal debt. As a suburb of the Los Angeles region, housing construction had accelerated in the up cycle. The dependence on housing construction for growth in property tax revenue and sales tax revenue that directly supported city and county government, created volatility in the revenue supporting local governments. Not only did property tax revenues decrease with mortgage industry collapse, but local sales tax revenues also decreased with reductions in purchases by construction and other industry workforces. The increase in unemployment further strained county government with additional demands for health and human services that county government provides by law as the final backstop. From a county perspective the increased demand for services occurs typically when county government is also experiencing a decline in revenue.

Prior to the 2008 economic collapse, as noted earlier, the loss of jobs in the region affected the County government. The job loss over several decades associated with closures by five large-scale employers, totaled in the range of 30,000 jobs. The recession led to an estimate that suggested that in the county almost half of homes with mortgages owed more on the homes than the homes were assessed at or able to sell for after the Great Recession. 
In addition to the external economic forces, litigation in the past decade connected to public corruption prosecutions affected the County of San Bernardino. County staff and an elected county supervisor were charged with corruption, and a \$104 million legal judgment was awarded to a developer resulting from a land use planning case action by the county.

\subsection{INSTITUTIONAL CONTEXT}

The county geographical responsibilities includes cities, such as the City of San Bernardino, as well as unincorporated areas where the county government directly provided services, as well as received the property taxes and other revenues traditionally assigned to cities. The county has a charter law structure, which allows the charter to be changed by initiative. As an extension of state government, counties in California are uniquely vulnerable to the volatility in state financing. In a state significantly dependent on a small percentage of residents paying considerable personal income tax and capital gains tax the result is acute state revenue sensitivity and reduction in economic downturns. In addition, as the cities in counties face economic downturns, additional financial pressures for public safety, redevelopment and other services can be placed on county government. Also, as the regional government structure, county governments can be significantly affected by the success or the limitations of regional agencies for transportation, air quality, water, economic development and other projects needing cross-jurisdictional cooperation.

Serving a population of over 2 million residents, the County of San Bernardino government has the five elected county supervisors, typical of California counties, each elected by district. As has been described of the adjacent Los Angles County, the power of county supervisors has been described as that of "five little kings". The five elected County Supervisors are both the elected legislative body responsible for passage of county ordinances and act with executive powers in hiring and firing senior administrative staff, along with oversight of the county's departments. Each supervisor set the priorities for their district, with little institutional incentives for coordination or priority setting across the five districts. Adding to the complexity, a range of special districts had been formed for fire protection and other services. There is no countywide elected executive, though the Sheriff and District Attorney are elected countywide. As a consequence, this governmental structure is seen as a unique combination of legislative and executive responsibilities in the same elected official.

\subsection{DECISION-MAKING}

The conditions needed for change by the County Board were created by a combination of external and internal features. Externally the pressures were the economic conditions, with the accompanying decline in revenues 
and increased pressures for services, as well as a public perception political ineffectiveness due to public corruption trials. Internally, the pressure was driven by a growing recognition of inefficiencies in the existing county administrative practices. Central to the political change was the selection of a former mayor, Gary Ovitt, as the Chairman of the Board of Supervisors. In addition, two new county supervisors were elected from their districts. These three of the five members of the board formed a constituency supporting new approaches to county governance.

The road to sustainable finances for the county started with the previous experience of Chairman Ovitt, who had served as Mayor of the City of Ontario. Ovitt experienced the executive powers exercised in the city manager form of government with the appointed executive responsible for getting the silos of city government to work together as needed in the county. From that experience, Ovitt developed a high regard for city manager, Greg Devereaux's leadership and management skills. As Chairman of the County Board of Supervisors, Ovitt successfully made the case for selection of Devereaux as new county chief administrative officer. The management experience of Devereaux that attracted county elected officials was also the same set of skills that facilitated his redesign of the CAO office structure in his employment contract negotiations. Devereaux negotiated an employment contract with the Board for his hiring as the de facto chief executive officer of the county government. Devereaux's contract assigned to his role that authority and responsibility across all the administrative units in the county. In addition, Devereaux's employment contract of five years provided a long term time horizon that minimized volatility in decision-making, insulated his office's from decision-making involvement of Board staff members, and assigned to his office the central oversight of county departments.

The hiring of a new individual was not as important for the success of the County, as was the new structure of that position. The past practice of department directors working directly with each of the five board members and their staffs was replaced with department directors reporting directly to Devereaux. The changes also allowed the Devereaux's office to improve hiring practices, as well as to consolidate staffing of a variety of commissions, regional agencies, and special purpose districts, improving communication and coordination across these former silos. The change in reporting created a structure that facilitated priority setting across departments and across the geography of the county. In particular, the new structure allowed budget priorities to be developed and implemented. The structure allowed cost savings to emerge, including the example set by the Board of Supervisors in reducing their staff from eleven to six, saving nearly one million dollars annually.

When the Board of Supervisors hired Devereaux to start in February 2010, the county faced a $10 \%$ deficit, totaling $\$ 80$ million in the general fund. The 
initial view of the Board of Supervisors was that the budget deficit was caused by the loss of revenue attributable to the economy. Initially, the Board of Supervisors did not view the deficit as a product of Board policy choices on negotiated labor agreements. The consequences of previous Board decisions on negotiated labor agreements became more apparent as expenditures continued to rise even as revenues stabilized.

Four factors were cited in interviews with county officials that describe the causes for the development of the structural budget deficit. First, the full costs of policy decisions were not presented for collective bargaining agreements. Second, the full costs of capital projects typically were not readily apparent in the approval projects. Third, cost shifting occurred as the county agreed to provide services to other jurisdictions without charging full overhead costs. Fourth, the county finance system was not fully integrated across all of the departments, particularly in terms of overhead and maintenance costs. The net effect was a difficulty for the Board of Supervisors to fully appreciate the long-term fiscal consequences of budget policy decisions.

In contrast to a case study of Los Angeles County (Pisano and Callahan, 2012), San Bernardino County officials had not fully developed the fiscal fluency needed for comprehensive budget discussions prior to the Board's appointment of Devereaux. Recognizing these shortcomings, Devereaux and the Board members developed a strategy to improve fiscal fluency. Initially the Chief Administrative Office integrated the finance tracing systems across all departments. Added to the reporting requirements were estimates of the full allocation of overhead administrative expenses. Department directors were required to use the new system. In addition, the budget presented to the Board of Supervisor included a ten-year forecast of expenditures.

In combination, these steps began a process of realistically assessing the County's fiscal position. The analysis projected on-going deficits in the absence of restructuring the county operations to reduce costs, re-negotiating collective bargaining salary and benefits cost containment, and facilitating an upswing in the regional economy. Devereaux consolidated administrative support functions including facilities management, real estate, architecture, and engineering to form one unit. This consolidation facilitated the transparency of budgeting for overhead costs charged within the county. Additionally, an effort was made for greater uniformity across the county in application of human resources and accounting practices. As a result of these initiatives, Devereaux had the experience of increasing the capacity for financial analysis, a greater shared fiscal fluency across departments, and an organizational culture of accounting for the full costs of current and future policy and budget decisions. 
A range of impacts occurred across county departments. For example, the Parks Department identified operations with high costs, initiating cost saving through developing partnerships with local cities to assist in operations. In one case, an excessively high utility bill was identified as due to a broken line, which when repaired resulted in an annual cost saving of over $\$ 700,000$. A unified fire services budget captured the costs of multiple districts operating across the county, identified cost reductions. The changes shifted the allocation of federal community development block grant funds as split across five Supervisorial Districts, to allocation based on highest needs on a countywide basis, leading to funding of a needed county wide emergency responders radio system.

The ten-year forecast fundamentally affected collective bargaining negotiations across 16 separate negotiations. The forecast showed the costs of continuing business as usual. Agreement were reached with each unit, resulting in different tiers of pension benefits, eliminating the county payment of a $7 \%$ pension match, and a 50\% reduction in salary increases, from 5\% annually to $2.5 \%$ annually.

\subsection{THE DYNAMICS FOR AVOIDING BANKRUPTCY}

Beyond the specifics of the budget decision-making process within the county government, Devereaux launched an initiative to connect county departments and decision-making with the 24 cities in the county, as well as other public and private sector organizations that comprised the civic infrastructure. Devereaux drew on his experience as City Manager of the City of Ontario, situated in San Bernardino County. Based on that experience, the strategy process examined the nexus between strategic planning, land use development and developing a business plan for the city. The business plan for city government leveraged resources to advance the strategy.

For the leaders of the County of San Bernardino government, the strategic planning process asked two questions central to the vitality of the county. One, where do residents and businesses in the county want to be in 20 years? Two, how to get to the description of 20 years into the future? The San Bernardino Associations of Governments convened meetings of the local governments county officials, and civic leaders, in their capacity as the federally designated metropolitan planning agency for the region. Devereaux emphasized the inclusion of contributions from each of the participating entities. The credibility of the process derived from the commitment of county elected and administrative leaders to develop a strategic approach to generating economic and environmental outcomes. Also, the strategy process committed to linking the county budget decision-making process with discussions of the long-term allocation of financial and environmental resources. As the process included long-term forecasting, one participant described the motivation for participation as sur- 
vival. A significant focus of the strategy process included consideration of the land use planning, with review of the general plans of unincorporated areas. Also, the demographics and land use projects were considered.

In discussions on the range of challenging issues and real constraints, eight elements emerged, with implementation expectation for achieving the goals such as "healthy for children" and "business friendly". Additional outcomes focused on human development. A significant finding was the need to coordinate county and city resources to leverage the assets needed for these outcomes. A specific example included better coordination between county and city operated public parks for functional improvements and financial savings. The strategy called for milestones to tie into budget cycles.

An innovative aspect of the strategy discussions evaluated the resources needed for long-term economic growth, coupled with land development. In a county with deserts, water resources emerged as a constraint on future economic growth; an expectation emerged for cooperation among formerly competing water resource agencies. The strategy discussion process legitimized the public and private water agencies jointly assessing the potential for coordination in addressing long-term water needs in the county. This cooperation can be seen as a breakthrough in connecting environmental and budget sustainability.

\section{PART III: ANALYSIS OF THE FINDINGS FOR DECISION- MAKING IN THE CONTEXT OF SPECIAL INTERESTS}

The expert panel in 2012 that reviewed the Haynes Foundation funded case studies on local government fiscal stress observed that representative governments have a difficult time in periods of economic decline. These two case studies, in the same time period, in the same region the choice of two different paths invite a deeper examination of the potential divergence in representative government confronting similar circumstances. The key features that differentiated the two case studies offer insights into the processes of democracy. The explanations connect the complex interactions of special interest politics in the budgeting process, the importance of a civic infrastructure, transparency to create capacity for understanding fiscal conditions, and processes that facilitate trust and accountability.

The budgets of general fund entities are to support all of the functions needed to achieve the mission of the jurisdiction and the wellbeing of all members. The role of the public safety bargaining units in the City had an effect of extracting resources. The charter amendments, supported by public safety constituency, altered the salaries and benefits increases of these operating units in effect depleted the fiscal capacity of the city. Similarly at the county level, the public safety constituencies supported a charter amendment 
that threatened to restrict the capacity of the County Board for actions advancing sustainability. This proposal was defeated narrowly.

\subsection{THE IMPACT OF CIVIC CULTURE}

Why and how did the civic culture in a city that just decades ago was recognized for its civic accomplishments as an All American City allow such a tactic to work. The answer most repeated is that people voted with their feet as suggested in the Tiebout formulation of public choice - resulting in leadership capacity moving out of the city. Business leaders moved their businesses. Some civic organizations lost their membership. Absentee landlords become the majority. The city did not lose population but the new residents were typically poorer. However, these changes alone do not explain the loss of civic culture.

John Gardner, past president of the National Civic League, explains this unfortunate loss of civic culture (Gardner, 1996). The key to community maintenance is the constant nurturing of all the organizations within the city: business, churches, labor, neighborhood associations, and education to support not just their interest but also the interests of the whole. The need for institutional arrangement for community maintenance is the most important role that organizations can perform. Over time these organizations will wane but that leaves a need for others to step up. A question emerges as to why the civic organizations that remained did not increase involvement to advance the interests of the city as a whole. This decline in organizational maintenance was noted in an urban design studio of the American Institute of Architects that looked at the possibility of an urban renaissance. The studio noted the lack of institutional capacity and alignment as the major limitation preventing the city from addressing physical regeneration as well as budget and capital improvements (American Institute of Architects, 1981, pp. 16-18).

\subsection{TRANSPARENCY AS POLITICAL CULTURE}

Transparency and involvement created understanding of fiscal and long run financial conditions in the County of San Bernardino. The strategic planning process that the County undertook utilized the convening capacity of the San Bernardino Council of Governments. This convening process involved the private sector and other interests in the County to create a broad, long-term perspective, enabled the referendum process to work. Involving all parties in the strategic planning process and discussing the budget's the long run goals facilitated connecting fiscal and environmental sustainability. Financial issues were discussed not simply as a financial problem but rather in the context of county needs over time and outcomes needed to renew the eroded economic base. This connection created real understanding within the leadership of or- 
ganizations within the county. The charter amendment battle occurred in this period.

The City of San Bernardino leadership during this period did not develop a shared understanding of future needs or the current financial conditions of the city. Members of the City Council and the City Attorney continually reiterated that they did not have financial information or that information provided was incorrect. These comments where made after repeated reports and briefings by multiple parties, over a long period of time, that presented evidence that the city was in serious financial shape and was in jeopardy of being insolvent. In the meeting that the City Council voted to file bankruptcy, the City Attorney and members of the City Council repeated these criticisms.

\subsection{LEADERSHIP AND TRUST}

Both organizations were in financial difficulty and the leadership in both undertook valiant efforts to right the ship. The final elements that enabled the County to pursue the path it did were the actions that the County Board took to establish trust and accountability in executive leadership. The employment agreement with the incoming Chief Executive Officer, created clear lines of authority for financial information within the county even over the budgets of elected public safety department heads. Within the City this was not the case. This is best exemplified by policies that were made through charter amendments. Additionally, the charter specifically stated that the sole and exclusive interpreter of the charter was the City Attorney. The City Attorney, who aligned with public safety constituencies, opposed the efforts by the Mayor to carry out the executive actions needed to reduce the fiscal imbalances.

The final authority for both entities still rested with the Board of Supervisors and the City Council, but the clarity of the employment agreement hiring the new top administrative position contrasted with the confusion that was created in the City Charter. This contrast helps explain the very different outcomes. The combination of the interaction of the structure - the city charter versus the county executive office-and the leadership provides the insights on why the two organizations followed different paths.

\subsection{DECISION-MAKING DRIVES OUTCOMES}

The City and the County were both on a collision course with fiscal default as the Great Recession unfolded. The net effect of the four factors described above shifts the explanation from the external economic environment to one that draws on very divergent internal decisions responding to the same economic downturn. The decision-making within the jurisdiction, not external pressures explain the divergence. 
The most common perception discussed in research interviews was that the charter of the City is the fundamental reason for fiscal problems. The structures of both jurisdictions are charter law jurisdictions so the feature of local home rule determination as a general principle does not describe the divergent paths. An alternative explanation suggested that the intergovernmental responsibilities of the County of San Bernardino provided a broader scope of activities with more fiscal options and flexibility. However, the County responsibility for implementation of highly regulated federal and state programs typically reduced fiscal options rather than expanding options. In addition, minimal budget matches required for federal and state program potentially further limited options for the general fund operations of the County. Consequently, this structural difference between city and county operations does not explain the different pathways.

\subsection{IMPLICATIONS}

The municipal bankruptcy filings in the recent past in California have revealed a deep tension between competing interests of the varied creditors. The conflicts that have recently emerged in the bankruptcy court in the City of Stockton case can be seen as a public precursor to the competing interests in the City of San Bernardino. The fundamental conflict is between the institutional lenders who purchased bonds for redevelopment and other municipal debt arguing that the city has honored the pension obligations and commitment to employees at the expense of repaying their debt. While only an observer in court, the California Public Employees Retirement System (CalPERS), the largest of its type in the nation, has a significant interest in the bankruptcy court requiring a city to meet all pension obligations prior to discharging other debt. Aligned with CalPERS are various public sector employee unions, wanting to preserve the pensions and retirement benefits of members.

However, the creditor argument becomes more complex with two significant factors. Institutional lenders arguing in court that the city, in the case of Stockton, California, had not sufficiently reduced current employee salary, benefits, and future pension obligations, with the city attorney claiming that salary costs have been curtailed to the largest extent possible. Treating future and current pensions as inviolable and non-negotiable, shifts funding to public employees past and current, reducing available funding for debt obligations. The second significant aspect of bankruptcy is an uncertainty in future proceedings. The ambiguity can have significant consequences for current budget negotiations, as well as for future borrowings. The bond market rewards local government and regional projects for reducing uncertainty (Callahan, 2007; Martell and Kravchuk, 2012). 
What emerges from the research is a lack of clarity in the institutional design, the rules of the game in the legal and financial community. The work of our case studies noted from several sources (GAO 2112; Pisano 2013) that the fiscal difficulties that governments at all levels are not due to short-term conditions but will last for decades. The legal and legislative framework that jurisdictions operate within create uncertainty and do not encourage fiscal literacy and understanding, particularly in periods of long term economic and fiscal stress. In the case of the City of San Bernardino, the lack of alignment among the organizations and interest groups used this lack of clarity in the rules of the game to further their interests. This is illustrated by the recommendation of the City Attorney to file for bankruptcy as a way to protect the interests of the interests of the city. The motion was opposed by the Mayor, but approved by the council. This issue is still under review in the legal system, but it is interesting to note that the majority of the debt of the city is pension obligations, which may cause the city to forgo the use of general funds for current operations to finance these obligations. This case may become a test of state law to protect pensions over the federal law of resolving the bankruptcy.

\section{CONCLUSION}

The research on these two cases is limited in generalizability, subject to the inherent limits of any sets of case studies. Future research can develop the exploratory findings suggested by this research as a basis for a confirmatory analysis across a larger data set. Some additional implications include the potential to anticipate the features that destabilize local government finances, the practices that advance fiscal sustainability, and the structure, strategies and leadership skills that can make a difference.

The unique alignment of overlapping and shared features between the City and County of San Bernardino explain bankruptcy as neither a product of unavoidable economic forces nor simply the result of structure. In this paper we show that leadership practices matter. The interaction between structure and leadership provide insights on why the two organizations followed different paths. The analysis of this comparison allows us to unbundle leadership and show that differences in strategy, processes that create transparency, civic culture and trust and accountability explain the different paths. Leadership practices can make a difference.

\section{REFERENCES}

American Institute of Architects. (1981) San Bernardino Regional Urban Design Assistance Team, October 18. 
Beckett, J. and Doamekpor, F.K. (2011) "Variability and opportunities in flexible budgeting: Local government approach", Public Finance and Management, 11(2): 93-117.

Callahan, R. F. (2012) "Moving beyond magical thinking: finding leadership, strategy, and fiscal sustainability in local government", National Civic Review, 101(2): 8-10.

. (2007) "Governance: the collision of politics and cooperation”, Public Administration Review, 67(2): 299-301

Chapman, J. I. (2008) "State and fiscal sustainability: the challenges", Public Administration Review, 68 (Supplemental): S115-S131.

City of San Bernardino. (2012) Comprehensive Annual Financial Report Year Ended June 30, 2012, San Bernardino, CA. . (2006) Comprehensive Annual Financial Report Year

Ended June 30, 2006, San Bernardino, CA.

County of San Bernardino. (2012) Comprehensive Annual Financial Report, Year Ended June 30, 2012, San Bernardino, CA.

. (2006) Comprehensive Annual Financial Report,

Year Ended June 30, 2006, San Bernardino, CA.

Gardner, J. W. (1996) "Building community", Prepared for the Leadership Studies Program of the Independent Sector, pp. 26-27.

Ghori, I. (2012) "Bankruptcy looms for city", The Press Enterprise, July 11. p. A1.

Hendrick, R. (2011) Managing the Fiscal Metropolis: The Financial Policies, Practices and Health of Suburban Municipalities, Washington, DC: Georgetown University Press.

Heinrich, C. J., Hill, C. and Lynn, Jr., L.E. (2004) "Governance as an organizing theme for empirical research", in: P.W. Ingraham and L.E. Lynn, Jr., (eds) The Art of Governance: Analyzing Management and Administration, pp. 3-19, Washington, DC: Georgetown University Press.

Korey, J. L. (2011) “California: Failed State or Too Big to Fail?", The California Journal of Politics \& Policy, 3:1-21. 
Martell, C. and Kravchuk, R. (2012) "The liquidity crisis: the 2007-2009 market impacts on municipal securities", Public Administration Review, 72(5): 668-677.

Morris, P. (2010) "Pair led irresponsible budgeting", The Sun, August 10. Opinion Section.

Moynihan, D. P. (2008) The Dynamics of Performance Management: Constructing information and Reform, Washington, D.C.: Georgetown University Press.

Ostrom, E. (1990) Governing the Common,. Cambridge: Cambridge University Press.

Pisano, M. and Callahan, R. F. (2013) "San Bernardino County case study", National Civic Review, 102 (2): 3-6.

Pisano, M. and Callahan, R.F. (2012) "Los Angeles County case study", National Civic Review, 101 (2): 11-17.

Pisano, M. (2013) "Demographics: the hidden drag on government budgets", paper presented at American Society for Public Administration National Conference, New Orleans, LA. March 18.

Sacco, J. F., Stalebrink, O. and Posner, P. (2011) "Introduction to the symposium on flexible budgeting", Public Finance and Management, 11(2): 86-92.

Slusher, T. (2012) "Book review of Fiscal Sociology and the Theory of Public Finance: An exploratory essay", Public Finance and Management, 12(2): 175-177.

United States General Accountability Office. (2012) State and Local Fiscal Outlook: April 12th Update.

Wagner, R. E. (2007) Fiscal Sociology and the Theory of Public Finance: An Exploratory Essay, Cheltenham: Edward Elgar.

Wall Street Journal. (2012) “As San Bernardino goes...”, July 12, p. A16

Walters, D. (2012) "Bankruptcy may rein in pensions", Sacramento Bee. November 5, p. A3.

Willow, P. (2012) "Now San Bernardino bankrupt", Los Angeles Times. July 11, p. A1. 
Wang, X., Hawkins, C.V., Lebredo, N. and Berman, E. (2012) "Capacity to sustain sustainability: a study of U.S. cities", Public Administration Review, 72(6): 841-852.

Wildavsky, A. B. (1961) "Political implications of budgetary reform", Public Administration Review, 21(4): 183-90.

Yin, R. K. (1994) Case Study Research: Designs and Methods (2 ${ }^{\text {nd }}$ ed.), Thousand Oaks: Sage.

\section{BIOGRAPHICAL SKETCH}

Richard Callahan, Chair, Department of Public and Nonprofit Administration, School of Management, University of San Francisco (Rfcallahan@usfca.edu).

Mark Pisano, Senior Fellow, Bedrosian Center, University of Southern California (mpisano@usc.price.edu). 
Reproduced with permission of the copyright owner. Further reproduction prohibited without permission. 